Jurnal Kesehatan Hesti Wira Sakti vol 8 No 22020

ISSN 2302-4283 (print)

ISSN 2580-9571 (online)

Online di https://jurnal.poltekkes-soepraoen.ac.id

DOI: $10.47794 /$ jkhws.v8i2

\title{
PERILAKU IBU DALAM PENCEGAHAN COVID-19 PADA ANAK USIA SEKOLAH DASAR
}

\author{
Ika Ayu Syabani ${ }^{1}$ \\ ${ }^{1}$ Instalasi Rawat Jalan RS dr. Soepraoen Malang \\ (Korespondensi: ikayusyabani@gmail.com )
}

\begin{abstract}
ABSTRAK
Pendahuluan Covid-19 adalah penyakit menular yang disebabkan oleh Coronavirus jenis baru dan ditetapkan sebagai pandemi. Anak termasuk kelompok rentan, angka kesakitan dan kematian anak akibat Covid-19 di Indonesia terbilang tinggi. Peran ibu dalam mencegah Covid-19 pada anak sangat diperlukan. Tujuan penelitian ini adalah untuk mengidentifikasi gambaran perilaku ibu tentang pencegahan Covid-19 pada anak usia sekolah dasar. Metode Penelitian ini merupakan penelitian deskriptif. Populasinya adalah ibu yang memiliki anak usia sekolah dasar di RT 08 RW 01 Desa Panggungrejo sebanyak 40 ibu. Teknik sampling yang digunakan adalah total sampling. Data diambil dengan menggunakan kuesioner. Analisis data menggunakan univariat. Data disajikan dengan distribusi frekuensi. Hasil penelitian menunjukkan hampir seluruhnya perilaku responden baik yaitu 31 ibu (78\%), sebagian kecil cukup dan kurang yaitu 8 ibu (20\%) dan 1 responden (2\%). Kesimpulan Ibu dengan tingkat pendidikan lebih tinggi, memiliki sikap percaya dengan adanya Covid-19, setuju dengan pencegahan Covid-19 pada anak, dan pernah mendapat informasi sebelumnya tentang Covid-19 cenderung memiliki perilaku yang baik. Perilaku ibu yang sudah baik perlu dipertahankan, perilaku ibu yang cukup dan kurang perlu ditingkatkan dengan membentuk sikap yang positif mengenai pencegahan Covid-19 pada anak.
\end{abstract}

Kata kunci: pencegahan, Covid-19, anak usia sekolah, perilaku ibu.

\begin{abstract}
Introduction Covid-19 is an infectious disease caused by a new type of coronavirus and is designated as a pandemic. Children are a vulnerable group, the number and mortality of children due to Covid-19 in Indonesia is quite high. The role of mothers in preventing Covid-19 in children is very necessary. The purpose of this study was to identify a description of mother's behavior regarding the prevention of Covid-19 in elementary school children. Methode This research was descriptive research. The population was mothers who had children of elementary school age in RT $08 R W 01$ Panggungrejo Village as many as 40 mothers. The sampling technique used total sampling. Data was taken using a questionnaire. Data analysis used univariate. The data were presented with a frequency distribution. Results The results showed that almost all of the respondents' behavior was good, namely 31 mothers (78\%), a small portion was moderate and less, namely 8 mothers (20\%) and 1 respondent (2\%). Conclusion Mothers with a higher level of education, had an attitude of belief in the existence of Covid-19, agreed with preventing Covid-19 in children, and had received previous information about Covid-19 tend to have good behavior. Mothers with good behavior needed to be maintaned, mothers with moderate and less behavior needed to be improved by forming a positive attitude regarding the prevention of Covid-19 in children.
\end{abstract}

Keywords: prevention, Covid-19, school-age children, mother's behavior 


\section{PENDAHULUAN}

Wabah

virus corona telah

ditetapkan sebagai pandemi oleh World

Health Organization (WHO). Virus corona dapat menyerang siapapun, tidak hanya orang dewasa, namun juga bisa menyerang anak-anak. Anak-anak termasuk kelompok rentan terhadap Covid-19. Temuan Ikatan Dokter Anak Indonesia (IDAI) menunjukkan angka kesakitan dan kematian anak akibat virus corona di Indonesia terbilang tinggi (Majni, 2020). Untuk itu, IDAI mendesak pemerintah dan berbagai pemangku kepentingan untuk mengambil keputusan dan melakukan tindakan berdasarkan kepentingan terbaik kesehatan dan kesejahteraan anak. Disini peran ibu sangat diperlukan di mana ibu nanti akan terlibat banyak dalam melindungi anak agar tidak mudah terpapar virus corona. Oleh karena itu, ibu perlu memiliki perilaku yang baik tentang pencegahan Covid-19 untuk diterapkan kepada anak. Jika ibu tidak memiliki perilaku yang baik dalam menerapkan pencegahan Covid-19, maka perlindungan terhadap anak akan kurang maksimal sehingga tidak menutup kemungkinan anak terpapar Covid-19 (Majni, 2020).

Menurut Wuragil (2020) dalam Ikatan Dokter Anak Indonesia (IDAI) kematian anak akibat Covid-19 di Indonesia saat ini tertinggi di Asia, bahkan di dunia. Secara keseluruhan, 70\% dari kasus Covid-19 pada anak berada di bawah usia enam tahun. Persentase tersebut lebih rincinya adalah $12 \%$ anak berusia 0-28 hari (baru lahir), 33\% berusia 29 hari-11 bulan, dan 25\% lainnya berusia 1-6 tahun. Sisanya, 30\% di kelompok usia 6-18 tahun. Mereka terdiri dari $12 \%$ berusia 6-9 tahun, dan $18 \%$ berusia 10-18 tahun. Berdasarkan hasil studi pendahuluan pada tanggal 24 September 2020 pada $10 \mathrm{ibu}$ yang memiliki anak usia sekolah dasar di RT 08 RW 01, didapatkan hasil ada 4 orang ibu yang sering menerapkan beberapa protokol kesehatan pada anak seperti memakaikan masker atau faceshield ketika mengajak anak keluar rumah dan mencuci tangan setelah dari luar rumah, 1 orang ibu kadang-kadang menerapkan penggunaan masker pada anak, dan 5 orang ibu lainnya belum mematuhi protokol kesehatan pada anak.

Ada anggapan bahwa anak-anak relatif lebih aman dari Covid-19. Kalaupun tertular, hanya akan menyebabkan dampak yang lebih ringan dibanding pada orang dewasa. IDAI membantah anggapan tersebut (Pramudiarja, 2020). Sama halnya orang dewasa, anak-anak yang terekspos virus ini bisa terinfeksi dan mengalami gejala-gejala Covid-19. Ada banyak cara yang mampu menunjukkan sistem kekebalan anak berbeda dari orang dewasa, 
paling tidak karena sistem kekebalan anak masih berproses. Anak-anak terutama yang berada di penitipan anak atau sekolah terekspos oleh infeksi pernapasan baru dan ini mungkin menyebabkan mereka memiliki tingkat antibodi yang tinggi terhadap virus daripada orang dewasa (Fernandes, 2020).

Ibu perlu memiliki perilaku bagaimana membekali dan mengajarkan protokol kesehatan pada anak sesuai anjuran. IDAI (2020) menganjurkan, upaya yang dilakukan untuk pencegahan Covid19 pada anak adalah tetap anjurkan anak untuk di rumah saja jangan diizinkan untuk keluar rumah tanpa pengawasan, jangan membawa anak-anak ke tempat umum (keramaian), memakai masker dan faceshield ketika bepergian, anjurkan untuk sesering mungkin cuci tangan, jaga jarak minimal 1 meter jika kontak dengan orang lain, menghindari memegang hidung, mata, dan mulut, tentunya pengawasan ini harus didampingi oleh ibunya. Menurut Majni (2020), jika ibu tidak memiliki perilaku yang baik dalam menerapkan pencegahan Covid-19, maka perlindungan terhadap anak akan kurang maksimal sehingga tidak menutup kemungkinan anak mudah terpapar penyakit-penyakit baru termasuk Covid-19.
Berdasarkan latar belakang di atas, maka penulis tertarik untuk melakukan penelitian mengenai gambaran perilaku ibu tentang pencegahan Covid-19 pada anak usia sekolah dasar di RT 08 RW 01 Desa Panggungrejo Kepanjen Kabupaten Malang.

\section{METODE PENELITIAN}

Desain penelitian yang digunakan dalam penelitian ini adalah deskriptif. Populasi penelitian adalah seluruh ibu yang memiliki anak usia sekolah dasar di RT 08 RW 01 Desa Panggungrejo Kepanjen Kabupaten Malang sejumlah 40 ibu. Sampel pada penelitian ini adalah seluruh ibu yang memiliki anak usia sekolah dasar di RT 08 RW 01 Desa Panggungrejo Kepanjen Kabupaten Malang sejumlah 40 ibu yang didapatkan dengan teknik total sampling. Variabel dalam penelitian ini yaitu perilaku ibu tentang pencegahan Covid-19 pada anak usia sekolah dasar yaitu suatu kegiatan atau aktivitas yang dilakukan ibu tentang pencegahan Covid19 pada anak. Data diambil dengan kuesioner yang terdiri atas 24 butir pernyataan yang terdiri dari 12 pernyataan positif dan 12 pernyataan negatif dengan pilihan jawaban yang terdiri dari selalu, sering, jarang, dan tidak pernah. Pernyataan positif selalu skor 3, sering skor 2, jarang 
skor 1 , tidak pernah skor 0 , pernyataan negatif selalu skor 0 , sering skor 1 , jarang skor 2, tidak pernah skor 3 sehingga skor tertinggi adalah 72, sedangkan skor terendah adalah 0 . Kriteria perilaku dikategorikan menjadi baik (48-72), cukup (24-47), dan kurang (0-23). Analisis data menggunakan analisis univariat. Data disajikan dalam distribusi frekuensi dengan bantuan SPSS 22.0.

\section{HASIL PENELITIAN}

Berdasarkan data karakteristik responden (Tabel 1) menunjukkan bahwa hampir setengahnya ibu yang memiliki anak usia sekolah dasar berusia 36-45 tahun (dewasa akhir) yaitu 18 responden (45\%), sebagian besar tidak bekerja yaitu 29 responden $\quad(72 \%), \quad$ setengahnya berpendidikan SMA yaitu 20 responden (50\%), hampir seluruhnya berpenghasilan $<$ Rp 3.018.053 (menengah ke bawah) yaitu 37 responden (92\%), hampir seluruhnya percaya dengan Covid-19 pada anak yaitu 34 responden $(85 \%)$, hampir seluruhnya setuju dengan adanya pencegahan Covid19 pada anak yaitu 38 responden (95\%), seluruhnya yaitu 40 responden pernah mendapatkan informasi tentang Covid-19 (100\%), dan hampir setengahnya mendapat informasi Covid-19 dari televisi dan lingkungan sekitar masing-masing yaitu 13 responden $(32 \%)$.
Berdasarkan data perilaku ibu tentang pencegahan Covid-19 pada anak usia sekolah dasar (Tabel 2) dari 40 orang menunjukkan hampir seluruhnya memiliki perilaku baik yaitu 31 responden (78\%), sebagian kecil memiliki perilaku cukup dan kurang yaitu 8 responden (20\%) dan 1 responden $(2 \%)$.

Tabel 1. Karakteristik Responden

\begin{tabular}{|c|c|c|}
\hline Data Umum & $\mathbf{n}$ & $\%$ \\
\hline \multicolumn{3}{|l|}{ Usia } \\
\hline 26-35 tahun (Dewasa Awal) & 13 & $32 \%$ \\
\hline 36-45 tahun (Dewasa Akhir) & 18 & $45 \%$ \\
\hline$>45$ tahun (Lansia) & 9 & $23 \%$ \\
\hline \multicolumn{3}{|l|}{ Pekerjaan } \\
\hline Bekerja & 11 & $28 \%$ \\
\hline Tidak bekerja & 29 & $72 \%$ \\
\hline \multicolumn{3}{|l|}{ Pendidikan } \\
\hline SD & 7 & $18 \%$ \\
\hline SMP & 8 & $20 \%$ \\
\hline SMA & 20 & $50 \%$ \\
\hline PT & 5 & $12 \%$ \\
\hline \multicolumn{3}{|l|}{ Penghasilan } \\
\hline $\begin{array}{l}<\text { Rp 3.018.053 (menengah ke } \\
\text { bawah) }\end{array}$ & 37 & $92 \%$ \\
\hline $\begin{array}{l}\geq \mathrm{Rp} \quad 3.018 .053 \text { (menengah- } \\
\text { menengah ke atas) }\end{array}$ & 3 & $8 \%$ \\
\hline \multicolumn{3}{|c|}{ Percaya Adanya Covid-19 pada Anak } \\
\hline Ya & 34 & $85 \%$ \\
\hline Tidak & 6 & $15 \%$ \\
\hline \multicolumn{3}{|c|}{$\begin{array}{l}\text { Setuju Tidaknya Pencegahan Covid-19 } \\
\text { pada Anak }\end{array}$} \\
\hline Setuju & 38 & $95 \%$ \\
\hline Tidak Setuju & 2 & $5 \%$ \\
\hline \multicolumn{3}{|c|}{$\begin{array}{l}\text { Pernah Tidaknya Mendapat Informasi } \\
\text { Covid-19 }\end{array}$} \\
\hline Pernah & 40 & $100 \%$ \\
\hline Tidak pernah & 0 & $0 \%$ \\
\hline Total & 40 & $100 \%$ \\
\hline
\end{tabular}

Sedangkan perilaku ibu berdasarkan data karakteristik responden (Tabel 3) menunjukkan bahwa ibu yang berpendidikan SMA hampir seluruhnya berperilaku baik dalam pencegahan Covid- 
19 pada anak usia sekolah dasar yaitu 18 responden (90\%) dan responden yang berpendidikan perguruan tinggi seluruhnya berperilaku baik yaitu 5 responden (100\%).

Responden yang percaya adanya

Covid-19 pada anak hampir seluruhnya berperilaku baik yaitu 28 responden ( $82 \%)$

Responden yang tidak percaya adanya Covid-19 pada anak setengahnya berperilaku baik yaitu 3 responden (50\%), hampir setengahnya berperilaku cukup yaitu 2 responden (33\%), dan sebagian kecil berperilaku kurang yaitu 1 responden (17\%). Responden yang setuju pencegahan Covid-19 pada anak hampir seluruhnya berperilaku baik yaitu 31 responden (82\%). Responden yang pernah mendapat informasi Covid-19 hampir seluruhnya berperilaku baik yaitu 31 responden (78\%).

Tabel 2. Perilaku Ibu tentang Pencegahan Covid-19 pada Anak Usia Sekolah Dasar

\begin{tabular}{lcc}
\hline \multicolumn{1}{c}{ Kategori } & n & \% \\
\hline Baik & 31 & $78 \%$ \\
Cukup & 8 & $20 \%$ \\
Kurang & 1 & $2 \%$ \\
\hline Total & $\mathbf{4 0}$ & $\mathbf{1 0 0 \%}$ \\
\hline
\end{tabular}

\section{PEMBAHASAN}

Berdasarkan hasil penelitian yang dilakukan mengenai gambaran perilaku ibu tentang pencegahan Covid-19 pada anak usia sekolah dasar di RT 08 RW 01 Desa Panggungrejo Kecamatan Kepanjen Kabupaten Malang diperoleh data bahwa hampir seluruh ibu berperilaku baik. Ibu dengan tingkat pendidikan lebih tinggi, memiliki sikap percaya dengan adanya Covid-19, setuju dengan pencegahan Covid-19 pada anak, dan pernah mendapat informasi sebelumnya tentang Covid-19 cenderung memiliki perilaku yang baik.

Faktor-faktor yang dapat mempengaruhi perilaku yaitu faktor sosiopsikologi (sikap, emosi, kepercayaan, kebiasaan, dan kemauan) dan situasional (faktor temporal, suasana, teknologi, sosial, dan ekonomi) (Notoatmodjo, 2010). Faktor yang dapat mempengaruhi perilaku ibu tentang pencegahan Covid-19 pada anak dalam penelitian ini adalah pendidikan, sikap dan kepercayaan (percaya tidaknya dan setuju tidaknya pencegahan Covid-19 pada anak), serta pernah tidaknya mendapat informasi Covid-19.

Menurut Notoatmodjo (2010) bahwa faktor pendidikan dan sikap dapat mempengaruhi perilaku. Pendidikan berarti bimbingan yang diberikan seseorang kepada orang lain terhadap sesuatu hal agar mereka dapat memahami. Semakin tinggi pendidikan seseorang, maka semakin mudah menerima informasi sehingga makin banyak pula pengetahuan yang dimiliki. Pengetahuan akan berpengaruh pada sikap. Pengetahuan sesorang tentang suatu obyek mengandung dua aspek yaitu 
positif dan negatif. Kedua aspek inilah yang akan menentukan sikap dan perilaku seseorang terhadap suatu obyek. Semakin banyak aspek positif dari obyek, maka akan semakin positif pula sikap terhadap obyek tersebut sehingga akan membentuk perilaku yang positif juga. Maka dari itu fakta dalam penelitian ini sejalan dengan teori tersebut. Responden dengan pendidikan perguruan tinggi dan SMA cenderung berperilaku baik karena anak dan setuju adanya pencegahan Covid19 pada anak.

Ibu yang memiliki perilaku kurang dalam pencegahan Covid-19 pada anak usia yaitu ibu yang memiliki pendidikan SD dan tidak setuju tentang pencegahan covid 19, meskipun pernah mendapatkan informasi tentang pencegahan Covid-19 sebelumnya. Hal tersebut sesuai dengan teori bahwa pendidikan yang kurang akan menghambat perilaku dan pengetahuan yang dimiliki

Tabel 3. Tabulasi Silang Karakteristik Responden dengan Perilaku

\begin{tabular}{|c|c|c|c|c|c|c|c|c|}
\hline \multirow{3}{*}{ Data Umum } & \multicolumn{6}{|c|}{ Perilaku } & \multirow{2}{*}{\multicolumn{2}{|c|}{ Total }} \\
\hline & \multicolumn{2}{|c|}{ Baik } & \multicolumn{2}{|c|}{ Cukup } & \multicolumn{2}{|c|}{ Kurang } & & \\
\hline & $\mathbf{n}$ & $\%$ & $\mathbf{n}$ & $\%$ & $\mathbf{n}$ & $\%$ & $\mathbf{n}$ & $\%$ \\
\hline \multicolumn{9}{|l|}{ Usia } \\
\hline 26-35 tahun (Dewasa Awal) & 10 & $77 \%$ & 3 & $23 \%$ & 0 & $0 \%$ & 13 & $100 \%$ \\
\hline 36-45 tahun (Dewasa Akhir) & 14 & $78 \%$ & 3 & $17 \%$ & 1 & $5 \%$ & 18 & $100 \%$ \\
\hline$>45$ tahun (Lansia) & 7 & $78 \%$ & 2 & $22 \%$ & 0 & $0 \%$ & 9 & $100 \%$ \\
\hline \multicolumn{9}{|l|}{ Pekerjaan } \\
\hline Bekerja & 9 & $82 \%$ & 2 & $18 \%$ & 0 & $0 \%$ & 11 & $100 \%$ \\
\hline Tidak bekerja & 22 & $76 \%$ & 6 & $21 \%$ & 1 & $3 \%$ & 29 & $100 \%$ \\
\hline \multicolumn{9}{|l|}{ Pendidikan } \\
\hline $\mathrm{SD}$ & 3 & $43 \%$ & 3 & $43 \%$ & 1 & $14 \%$ & 7 & $\mathrm{c}$ \\
\hline SMP & 5 & $62 \%$ & 3 & $38 \%$ & 0 & $0 \%$ & 8 & $100 \%$ \\
\hline SMA & 18 & $90 \%$ & 2 & $10 \%$ & 0 & $0 \%$ & 20 & $100 \%$ \\
\hline PT & 5 & $100 \%$ & 0 & $0 \%$ & 0 & $0 \%$ & 5 & $100 \%$ \\
\hline \multicolumn{9}{|l|}{ Penghasilan } \\
\hline $\begin{array}{l}<\text { Rp 3.018.053 (menengah ke } \\
\text { bawah) }\end{array}$ & 28 & $76 \%$ & 8 & $22 \%$ & 1 & $2 \%$ & 37 & $100 \%$ \\
\hline $\begin{array}{l}\geq \text { Rp 3.018.053 (menengah- } \\
\text { menengah ke atas) }\end{array}$ & 3 & $100 \%$ & 0 & $0 \%$ & 0 & $0 \%$ & 3 & $100 \%$ \\
\hline \multicolumn{9}{|c|}{ Percaya Adanya Covid-19 pada Anak } \\
\hline Ya & 28 & $82 \%$ & 6 & $18 \%$ & 0 & $0 \%$ & 34 & $100 \%$ \\
\hline Tidak & 3 & $50 \%$ & 2 & $33 \%$ & 1 & $17 \%$ & 6 & $100 \%$ \\
\hline \multicolumn{9}{|c|}{ Setuju Tidaknya Pencegahan Covid-19 pada Anak } \\
\hline Setuju & 31 & $82 \%$ & 7 & $18 \%$ & 0 & $0 \%$ & 38 & $100 \%$ \\
\hline Tidak Setuju & 0 & $0 \%$ & 1 & $50 \%$ & 1 & $50 \%$ & 2 & $100 \%$ \\
\hline \multicolumn{9}{|c|}{ Pernah Tidaknya Mendapat Informasi Covid-19 } \\
\hline Pernah & 31 & $78 \%$ & 8 & $20 \%$ & 1 & $2 \%$ & 40 & $100 \%$ \\
\hline Tidak pernah & 0 & $0 \%$ & 0 & $0 \%$ & 0 & $0 \%$ & 0 & $0 \%$ \\
\hline
\end{tabular}

memiliki informasi dan sikap yang positif terhadap Covid-19 pada anak dibuktikan dengan percaya adanya Covid-19 pada Jurnal Kesehatan Hesti Wira Sakti sehingga akan mempengaruhi sikap sesorang. Semakin banyak aspek negatif suatu obyek, maka akan semakin negatif 
pula sikap seseorang sehingga akan membentuk perilaku yang negatif juga. Namun tidak semua yang memiliki pengetahuan bersikap dan berperilaku baik. Walaupun melalui informasi untuk mendapat pengetahuan ada pula yang berperilaku kurang. Selain itu, kepercayaan juga menjadi faktor lain. Kepercayaan di sini hanya sebatas keyakinan bahwa sesuatu itu benar atau salah (Notoatmodjo, 2010). Responden yang berperilaku kurang dalam penelitian ini merupakan sebagian responden yang tidak percaya Covid-19 pada anak dan tidak setuju adanya pencegahan Covid-19 pada anak. Sehingga juga menimbulkan perilaku pencegahan Covid-19 pada anak yang kurang meskipun sudah pernah mendapat informasi tentang Covid-19 pada anak sebelumnya.

Upaya untuk meningkatkan perilaku ibu perlu dilakukan dengan mengadakan kegiatan promosi kesehatan melalui kegiatan sosialisasi, edukasi, dan penggunaan berbagai media informasi untuk memberikan pengertian dan pemahaman bagi semua orang, serta keteladanan dari pimpinan, tokoh masyarakat, dan melalui media mainstream. Dilakukannya sosialisasi dan koordinasi dengan Kader Kesehatan yang ada di lingkungan ibu tentang pencegahan Covid-19 pada anak secara mandiri yang bisa dilakukan di rumah (Kemenkes RI, 2020).

\section{KESIMPULAN}

Berdasarkan hasil penelitian yang dilakukan mengenai gambaran perilaku ibu tentang pencegahan Covid-19 pada anak usia sekolah dasar di RT 08 RW 01 Desa Panggungrejo Kecamatan Kepanjen Kabupaten Malang dapat disimpulkan bahwa hampir seluruh ibu berperilaku baik. Ibu dengan tingkat pendidikan lebih tinggi, memiliki sikap percaya dengan adanya Covid-19, setuju dengan pencegahan Covid-19 pada anak, dan pernah mendapat informasi sebelumnya tentang Covid-19 cenderung memiliki perilaku yang baik. Berdasarkan hasil tersebut disarankan Tenaga kesehatan Puskesmas dan Kader di lingkungan sekitar sebaiknya memberikan penyuluhan dengan menggunakan bahasa yang mudah dimengerti dan menggunakan metode-metode yang kreatif kepada masyarakat untuk meningkatkan dan mempertahankan perilaku ibu tentang pencegahan Covid-19 pada anak. Responden diharapkan lebih meningkatkan pengetahuan dari informasi tentang Covid19 yang diperoleh guna untuk meningkatkan sikap dalam menerapkan protokol kesehatan tentang pencegahan Covid-19 pada anak. 


\section{DAFTAR PUSTAKA}

Ananda, Ferdian. 2020. Anak Rentan Terpapar Covid-19, Media Indonesia 28 Mei.

Fernandes, Michelle. 2020. Virus Corona: Mengapa Anak-Anak Tidak Imun Terhadap Covid-19?, BBC Future 7 April.

Ikatan Dokter Anak Indonesia. 2020. Anjuran Ikatan Dokter Anak Indonesia Mengenai Aktivitas Anak di Luar Rumah Selama Masa Pandemi Covid19. Jakarta: Pengurus Pusat Ikatan Dokter Anak Indonesia.

Intan, Ghita. 2020. Tingkat Kematian Anak Indonesia Akibat Covid-19 Tertinggi di $A S E A N$, Voa Indonesia 30 Mei.

Kemenkes RI. 2011. Kebutuhan Dasar Anak Untuk Tumbuh Kembang yang Optimal. Jakarta: Kemenkes RI.

Kemenkes RI. 2020. Pedoman Pengendalian dan Pencegahan Coronavirus Disease (Covid-19). Jakarta: Kemenkes RI.

Komarudin. 2020. IDAI: Tingkat Kematian Anak Akibat Covid-19 di Indonesia Tertinggi di Asia Pasifik, Liputan 614 Agustus.

Majni, Ferdian A. 2020. Anak Rentan Terpapar Covid-19, Media Indonesia 28 Mei.

Nabila, Mutiara. 2020. Cegah Penularan Corona, Berikut Tips Protokol Kesehatan untuk Anak, Bisnis Lifestyle 23 Juli.

Notoatmodjo, P. D. 2010. Ilmu Perilaku Kesehatan. Jakarta: Rineka Cipta.

Notoatmodjo, P. D. 2014. Promosi Kesehatan dan Perilaku Kesehatan. Jakarta: Rineka Cipta.
Nursalam. 2016. Metodologi Penelitian Ilmu Keperawatan: Pendekatan Praktis Edisi 4. Jakarta: Salemba Medika.

Pramudiarja, Uyung. 2020. Anak-anak Tidak Rentan Virus Corona? Data IDAI Ungkap Fakta Sebaliknya, Detik Health 23 Mei.

Rossa, Vania. 2020. IDAI: Kasus Covid-19 pada Anak di Indonesia Masih Tinggi, Suara.com 01 Juni.

Siyoto, S dan Ali Sodik. 2015. Dasar Metodologi Penelitian. Yogyakarta: Literasi Media Publishing.

Suparyanto. 2011. Konsep dan Peran Ibu. Yogyakarta : http://drsuparyanto.blogspot.com/2011/05/k onsep-ibu.html.

Syifa, Putri. 2020. IDAI: Anjuran Aktivitas Anak di Luar Rumah Selama Pandemi Covid-19, Popmama 20 Juni.

Taslim. 2018. Peran Ibu Rumah Tangga dalam Mewujudkan Kesejahteraan Keluarga. Makassar: Universitas Alauddin.

Trimutia, Raden. 2020. Alasan WHO Tetapkan Virus Corona COVID-19 Sebagai Pandemi, Liputan 612 Maret.

Werdiningsih, A.T.A \& Astarini, K. 2012. Peran Ibu Dalam Pemenuhan Kebutuhan Dasar Anak Terhadap Perkembangan Anak Usia Prasekolah. Jurnal STIKES RS Baptis Kediri. (5: 82-90).

Wuragil, Zacharias. 2020. Data IDAI: 2.712 Anak di Indonesia Positif Corona, 51 Meninggal, Tempo 24 Juli. 